\title{
Islamic Peril: Media and Global Violence
}

Karim H. Karim

Montréal: Black Rose, 2003. 208 pages.

At the junction of history, international relations, political science, and communication studies, Karim H. Karim's Islamic Peril provides serious and in-depth research on the media coverage of violence involving Muslim individuals and groups. This updated edition of the book, first published in 2000, adds a preface and an afterword that briefly account for $9 / 11$ and its aftermath. While studying the construction of Islam as the primary "Other" in Canada's main print media since the beginning of the 1980s, the author argues that the numerous (mis)representations and stereotypes of Muslims are based on a lack of religious, sociological, political, and historical knowledge rather than on what Karim calls a "centrally organized journalistic conspiracy against Islam" (p. 4).

The author concentrates on the construction, flow, and reproduction of globally dominant interpretations through relations of power and domination between the North and the South, but also inside the North's media. His focus on journalism's internal mechanisms (e.g., dependence on a limited number of sources, the need for simplification, and the clash of interests between information and business) and the wider sociopolitical domination processes (e.g., the end of the cold war or unipolarity) prevents the analysis from being overtly simplistic and adopting a victim mentality. The author does not just highlight the (mis)representations; he also tries to analyze them. His approach is optimistic, for it implies there is no fatality in reproducing stigmatization and stereotypes.

Karim studies what could be called the "Islamization of representations": the social construction of the linkage between facts of violence that are historically and sociologically rooted and the notion of Islam as an essence. His analysis does not revolutionise the approach toward discourses on Islam, for one can feel how much he was influenced by the founding 
works of such scholars as Edward Said or Fred Halliday to whom, among others, references are frequently made). Yet this lack of theoretical originality is balanced by the impressive amount of documentation gathered and the different events covered and analyzed, including some that few readers might recall: the hijacking of a TWA plane in 1985 or the Azeri-Armenian war over Nagorno-Karabakh in 1992.

Indeed, this research gathers original facts and examples that confirm several perceptions that many people share about how Muslims and Islam are portrayed in dominant discourses but are not always able to formulate. On that matter, his analysis of the construction of jihad as a martial concept or of the way Saddam Hussein emerged during the 1990-91 Gulf war as an Islamic figure, although he appeared as a secularist leader in the 1980s, are particularly convincing. The emphasis on the role of certain intellectuals, whom Karim calls "ideologues" (p. 139), such as Bernard Lewis, V. S. Naipaul, or Daniel Pipes, in spreading and legitimizing stereotypes of Muslims is truly interesting. Yet it also strengthens the impression that the author sometimes loses sight of the Canadian print media and wishes to tackle the whole question of constructing representations.

The main weakness of the analysis is its lack of a dynamic approach. Throughout the 20 years of the study, which saw, among other things, the end of the cold war, Karim does not seem to point out any fundamental transformation in the dominant (mis)representations of Muslims and Islam. Only in his final chapter does he announce the possibility of going beyond the dominant stereotypes on Islam and of doing "conscientious reporting." Nevertheless, the author's starting point and conclusions do not differ from those that Edward Said conceptualized in Covering Islam (1981) and, to some extent, in Orientalism (1978). Have things not changed at all? Are the props of stigmatization always the same?

In any western society, and at any time, one could probably find in the media, within governments, and among experts and scholars many examples of essentialist discourses that portray Islam as the primary "Other" and that directly link it to violence. As Islamic Peril does, these stigmatizing and stereotyped discourses then could be brilliantly analyzed and deconstructed. Yet, that approach seems to leave out a fundamental question: Are these essentialist discourses on Islam the only ones and/or the most significant ones throughout time and space? If one cannot deny the existence of what could be called Islamophobia (Karim never uses the word), are we sure that it is always characterized in the same way and that it is still the dominant discourse on Islam? 
The dissemination of information over the Internet, the multiplication of alternative sources of information, and the rise of the South's global media, of which Al-Jazeera is just an example, most probably change the mechanisms of domination and, therefore, influence how the representations of Muslims are constructed. In addition, the ambiguous effects of 9/11, which Karim briefly acknowledges in his afterword, probably have eased the spread of different forms of the stigmatization of Muslims that are not based primarily on a global approach toward Islam, but rather on a distinction between "good" and "bad" Muslims.

This still essentialist binary vision, which many in the media and governments adopt when they claim that the war on terror is being waged against terrorists and not Islam, therefore considers the clash to be inside Islam and not between "Islam" and the "West." Obviously, highlighting the spread of the good/bad distinction does not mean that other forms of stigmatization (including those studied in Islamic Peril) are deemed irrelevant; it only advocates for a dynamic and a contextualized analysis of the media's coverage of Islam and Muslims that, unfortunately, Karim does not put at the center of his investigation. The over-multiplication of sources, angles, events, and levels of analysis, as well as the lack of dynamism, do not, however, question the relevance and seriousness of this research, which everyone should be encouraged to read.

Laurent Bonnefoy

Ph.D. Candidate, Centre d'Etudes et de Recherches Internationales

Institut d'Etudes Politiques (Sciences-Po)

Paris, France 